\title{
PERBEDAAN KECERDASAN EMOSI ANTARA PERAWAT LAKI-LAKI DAN PERAWAT PEREMPUAN
}

\section{THE EMOTIONAL QUOTIENT DIFFERENCE BETWEEN MALE AND FEMALE NURSE}

\author{
Oleh : \\ Satrio Nugroho*) \\ Retno Dwiyanti **)
}

\begin{abstract}
ABSTRAK
Penelitian ini bertujuan mengetahui perbedaan dan melihat tingkat kecerdasan emosi antara perawat laki-laki dan perawat perempuan di Rumah Sakit Wijayakusuma Purwokerto. Subjek pada penelitian ini berjumlah 94 perawat di Rumah Sakit Wijayakusuma Purwokerto yang terbagi menjadi dua kelompok yaitu 35 perawat laki-laki dan 59 perawat perempuan. Metode pengumpulan data yang digunakan pada penelitian ini adalah metode kuesioner dengan instrumen skala kecerdasan emosi. Hasil uji validitas melalui try out terpakai terhadap 94 perawat diperoleh koefisien validitas yang bergerak dari mulai 0,316 sampai 0,741 dengan standar Azwar sebesar 0,3 dan taraf signifikansi sebesar 5\% (0,05). Sedangkan hasil uji reliabilitas skala kecerdasan emosi diperoleh nilai $\alpha$ sebesar 0,915. Berdasarkan hasil uji hipotesis dengan menggunakan teknik uji-t diperoleh $t_{\text {hitung }}$ sebesar 4.879 dengan nilai probabilitas 0,000 . Oleh karena itu $t_{\text {tabel }}$ dengan df (n-2) sebesar 92 dan menggunakan taraf signifikansi $1 \%(0,01)$ yaitu sebesar 2,630, maka $t$ hitung $>t$ tabel yaitu $(4,879>$ 2,630) dan nilai probabilitas lebih kecil dari $1 \%(0,01)$ yaitu $(0,000<0,01)$. Hasil uji mean, maka diketahui bahwa mean untuk kecerdasan emosi perawat laki-laki yaitu 149.06 lebih besar dari mean kecerdasan emosi perempuan yaitu 135.63. Dengan standar deviasi (SD) kecerdasan emosi perawat laki-laki yaitu 14.138 dan standar deviasi (SD) kecerdasan emosi perempuan yaitu 12.117. Dengan demikian, maka dapat disimpulkan bahwa hipotesis pada penelitian ini adalah diterima, berarti ada perbedaan yang signifikan kecerdasan emosi antara perawat laki-laki dengan perawat perempuan dan kecerdasan emosi perawat laki-laki lebih tinggi daripada perawat perempuan di Rumah Sakit Wijayakusuma Purwokerto.
\end{abstract}

Kata Kunci : Kecerdasan Emosi, Perawat Laki-laki, Perawat Perempuan.

\section{ABSTRACT}

This research is aimed to know the difference and see the emotional quotient level of male and female nurse in Wijayakusuma Hospital of Purwokerto. The subject of this research was 94 nurses in Wijayakusuma Hospital of

\begin{tabular}{ll}
\hline *) Alumni Fakultas Psikologi Universitas Muhammadiyah Purwokerto \\
**) Dosen Fakultas Psikologi - Universitas Muhammadiyah Purwokero
\end{tabular} 
SATRIO NUGROHO \& RETNO DWIYANTI, Perbedaan Kecerdasan Emosi Antara Perawat Laki-Laki Dan Perawat Perempuan

Purwokerto that was divided into 2 groups; 35 male nurses and 59 female nurses. The method for collecting data in this research was estionnaire method with the instument of emotional quotient scale. The result of validity tes through try out test that involved 94 nurses obtained coefficient validity that moved from 0.316 to 0.741 with Azwae standard 0.3 and significient level 5\% (0.05). in addition, the result of reliability test of emotional quotient difference obtainded score $\alpha=$ 0.915. The result of hypothesis test by using T-Test showed thatscore of $t_{\text {obtain }}$ was 4.879 with probability score 0.000. therefore, the score of $t_{\text {table }}$ was 2.630 with $d f$ $(n-2)=92$ and significance level $1 \%(0.01)$, therefore $t_{\text {obtain }>} t_{\text {table }}(4.879>2.630)$ and probability score was lower than $1 \%(0.01)$ or $(0.000<0.01)$. the result of mean test showed that mean score of male nurse 149.06 was higher than mean score of female nurse 135.63 with deviation standard of male nurse was 14.138 and deviation standard of female nurse was 12.117. thus, it can be conculuded that the hypothesis of this research is accepted, it means that there is significant difference in emotional wuotient between male and female nurse since the emotional quotient of male nurse is higher than the emotional quotient of female nurse in Wijayakusuma Hospital of Purwokerto.

Keywords: Emotional Quotient, Male Nurse, Female Nurse

\section{PENDAHULUAN}

Salah satu organisasi yang sangat terkait dengan bidang jasa adalah rumah sakit. Rumah sakit merupakan organisasi yang bersifat sosial selain juga komersil. Sumber daya manusia yang ada di rumah sakit perlu sekali mendapatkan perhatian khusus. Salah satunya adalah perawat yang mempunyai peluang lebih lama untuk berhubungan dengan pasien dan melayaninya. Jam kerja pada rumah sakit pada umumnya adalah 24 jam, walaupun ada shif untuk kerjanya. Hal tersebut tetap menjadikan perawat sebagai orang yang paling dekat dengan pasien, mereka harus siap melayani setiap pasien yang ada.

Di dunia manusia diciptakan dengan dua jenis kelamin yaitu, laki-laki dan perempuan. Perbedaan antara laki-laki dan perempuan merupakan prinsip yang universal dalam masyarakat, dimana keduanya memilikiperbedaan dari beberapa segi baik fisik, karakteristik dan emosi, perempuan umumnya lebih bersifat tidak agresif, memelihara, lemah lembut dan keibuan sehingga cenderung sensitif sedangkan laki-laki cenderung bersifat agresif dan penuh daya serang untuk menguasai situasi ruang lingkup hidupnya. Berdasarkan perbedaan tersebut maka kemungkinan perempuan akan lebih mudah berempati sehingga menjadi lebih mudah memaafkan daripada laki-laki ketika disakiti orang lain.

Meaty (dalam Winahyu, 2009) menjabarkan perbedaan segi psikologis laki-laki dan perempuan, yaitu perempuan lebih peka bila ada perempuan lain yang marah atau terluka, sementara laki-laki biasanya masih harus secara nyata melihat air mata, wajah marah sebelum benar-benar mengerti apa yang terjadi. Kepekaan perempuan dalam memahami isyarat komunikasi yang halus dan samar 
ini sering disebut sebagai "intuisi perempuan"e yang sebenarnya adalah kemampuan perempuan yang luar biasa dalam mendeteksi detil dan perubahan kenampakan atau perilaku orang lain.

Perawat laki-laki dan perempuan memiliki standar kinerja profesional yang sama, yaitu standar kualitas pelayanan, penilaian kinerja, pendidikan, kolegialitas, etika, kolaborasi, penelitian, pemanfaatan sumber daya. Didalam standar kinerja profesional perawat laki-laki dan perawat perempuan mempunyai tugas yang samaseperti yang di tulis dalam surat tugas dari kepala instal rawat inap Detasemen Kesehatan Wilayah 04.04.01 Rumah Sakit Tk III 04.06.01 Wijayakusuma.

Dari pihak rumah sakit menyamaratakan tugas untuk perawat laki-laki dan perawat perempuan tidak dibedakan berdasaran gender atau kemampuan yang membedakan antara laki-laki dan perempuan, sehingga pada pelaksanaanya tidak sesuai dengan standar kinerja profesional yang dapat dillihat dari hasil penilaian kinerja perawat laki-laki memperoleh nilai 4287 sedangkan perawat perempuan memperoleh nilai 4200. Dari hasil penilaian tersebut perawat laki-laki lebih unggul dari hasil kinerja perawat perempuan.

Dari hasil tersebut maka akan lebih baik jika tugas tugas perawat perempuan dan laki-laki dibedakan berdasarkan hasil penilaian kerja agar dapat memberikan pelayanan yang optimal sehingga pasien dapat merasakan kepuasan dari pelyanan yang di berikan perawat. Karena perawat merupakan sebuah profesi yang berorientasi kepada pelayanan dalam bentuk jasa. Pelayanan diberikan kepada pasien, baik sebagai individu, keluarga maupun masyarakat. Agar pelayanan yangdiberikan paripurna meliputi aspek biologi, psikologi, sosial dan spiritual diperlukansuatu keterampilan manajemen emosi. Keterampilan tersebut lebih dikenal dengan istilah kecerdasan emosional.

Menurut Goleman kecerdasan emosional adalah kemampuan seseorang mengatur kehidupan emosinya dengan intelegensi menjaga keselarasan emosi dan pengungkapannya melalui keterampilan kesadaran diri, pengendalian diri, motivasi diri, empati dan keterampilan sosial. Pekerjaan seperti perawat yang harus selalu berinteraksi langsung dengan pasien, diperlukan kemampuan mengenali emosi, kemampuan mengelola emosi, kemampuan memotivasi diri sendiri, kemampuan mengenali emosi orang lain dan kemampuan membina hubungan dengan orang lain, sehingga akan terjalin hubungan saling percaya dan saling membantu antara perawat dengan pasien, perawat dengan keluarga, perawat dengan dokter, perawat dengan tim kesehatan yang lainnya.

Menurut Goleman (2000) aspek-aspek yang terkandung dalam kecerdasan emosi adalah sebagai berikut: (1) Mengenali emosi diri, yaitu kemampuan individu untuk mengenali perasaan sesuai dengan apa yang terjadi, mampu memantau perasaan dari waktu ke waktu dan merasa selaras terhadap apa yang dirasakan; (2) Mengelola emosi, yaitu kemampuan untuk menangani perasaan sehingga perasaan dapat ditangkap dengan tepat; kemampuan untuk menenangkan diri, melepaskan diri dari kecemasan, kemurungan dan kemarahan yang menjadi- 
jadi; (3) Memotivasi diri sendiri, yaitu kemampuan untuk mengatur emosi sebagai alat untuk mencapai tujuan, menunda kepuasan dan merenggangkan dorongan hati, mampu berada dalam tahap flow; (4) Mengenali emosi orang lain, yaitu kemampuan mengetahui perasaan orang lain (kesadaran empatik), menyesuaikan diri terhadap apa yang diinginkan orang lain; (5) Membina hubungan, yaitu kemampuan mengelola emosi orang lain dan berinteraksi secara mulus dengan orang lain.

Beberapa penelitian menemukan bahwa wanita lebih menyadari emosi mereka, menunjukkan empati dan lebih baik dalam hubungan interpersonal dibandingkan dengan pria. Penelitian yang dilakukan oleh King (1999), Sutarso (1999), Wing dan Love (2001) dan Singh (2002) (dalam Sarhad, 2009) juga menunjukkan bahwa wanita memiliki kecerdasan emosi yang lebih tinggi daripada pria. Goleman (1997) mengatakan wanita lebih beruntung pada lingkungan sosial yang lebih menekankan kepada emosi daripada pria.

\section{METODE PENELITIAN}

\section{Identifikasi Variabel Penelitian}

Sugiyono (2010) mengatakan variabel didalam penelitian merupakan suatu atribut dari sekelompok objek yang di teliti yang mempunnyai variasi antara satu dengan yang lain di dalam kelompok tersebut. Didalam penelitian ini terdapat satu variabel penelitian yaitu Kecerdasan Emosi.

\section{Definisi Operasional Variabel}

Kecerdasan emosional adalah kemampuan seseorang mengatur kehidupan emosinya dengan inteligensi menjaga keselarasan emosi dan pengungkapannya melalui keterampilan kesadaran diri, pengendalian diri, motivasi diri, empati dan keterampilan sosial. Aspek-aspek yang digunakan untuk mengukur kecerdasan emosi yaitu mengenali emosi diri, mengelola emosi, memotivasi diri sendiri, mengenali emosi orang lain, dan membina hubungan.

\section{Populasi Dan Sampel}

Saryono (2011) mendefinisikan populasi merupakan keseluruhan sumber data yang diperlukan dalam suatu penelitian. Populasi daripenelitian ini adalah seluruh perawat laki-laki dan perempuan di Rumah Sakit Wijayakusuma Purwokerto yang berjumlah 113 perawat diantaranya 35 perawat laki-laki dan 78 perawat perempuan.

Teknik pengambilan sampel dalam penelitian ini adalah total sampling. Total sampling adalah teknik pengambilan sampel dimana jumlah sampel sama dengan populasi (Sugiyono, 2007). Alasan mengambil total sampling karena menurut Sugiyono (2007) jumlah populasi yang kurang dari 100 seluruh populasi dijadikan sampel penelitian semuanya. 


\section{Metode Pengumpulan Data}

Metode pengumpulan data menurut Arikunto (2010) dalam kegiatan penelitian mempunyai tujuan untuk mengungkap fakta mengenai variabel yang akan diteliti. Sedangkan alat untuk mengumpulkan datanya tersebut dinamakan instrumen. Pada penelitian ini, instrumen pengumpulan data yang digunakan adalah metode skala. Dalam penelitian ini penulis menggunakan skala kecerdasan emosional.

Skala kecerdasan emosional terdiri dari aspek mengenali emosi diri, mengelola emosi diri, memotivasi diri sendiri, mengenali emosi orang lain (empati), bekerjasama dengan orang lain, yang berguna untuk mengetahui perbedaan kecerdasan emosi antara perawat laki-laki dan perwat perempuan di Rumah Sakit Wijayakusuma Purwokerto.

\section{Validitas Dan Reliabilitas Instrumen}

Menurut Azwar (2009) validitas digunakan untuk mengetahui sejauh mana instrumen mampu mengukur atribut yang seharusnya diukur. Uji validitas didasarkan pada validitas isi, yakni telaah dan revisi butir pernyataan berdasarkan pendapat profesional (professional judgment) dan mencari korelasi antara tiap-tiap aitem skor total aitemnya yang disebut dengan model uji validitas internal validity. (Suryabrata, 2005).

Untuk menguji validitas internal digunakan teknik korelasi product moment dari Pearson (Azwar, 2010). Pernyataan dapat dinyatakan valid apabila dalam pengujian validitas diperoleh nilai korelasi tiap-tiap pernyataan di atas 0,30 (Azwar,2009).

Berdasarkan hasil try out dari 50 aitem pernyataan skala kecerdasan emosi terhadap 94 perawat, diperoleh koefisien validitas yang bergerak dari mulai 0,316 sampai 0,741 dengan standar (Azwar, 2010) sebesar 0,3 dan taraf signifikansi (£) sebesar 5\% (0,05). Sehingga dari hasil try out tersebut, dapat dinyatakan bahwa dari 50 aitem pernyataan skala Kecerdasan Emosi terdapat 45 aitem yang valid dan 5 aitem dinyatakan gugur, hal ini dikarenakan $r$ hitung lebih kecil dari 0,3 standar (Azwar, 2010).

Uji reliabilitas digunakan untuk menguji tingkat sejauh mana kestabilan hasil suatu pengukuran dapat dipercaya. Hasil pengukuran dapat dipercaya apabila dalam beberapa kali pelaksanaan pengukuran terhadap kelompok subjek yang sama diperoleh hasil yang relatif sama selama aspek yang diukur dalam diri subjek belum berubah (Azwar, 2010). Teknik Alpha yang dikembangkan Cronbach dipilih untuk mengukur reliabilitas antar aitem yang paling populer dan menunjukkan indeks konsistensi yang cukup sempurna.

Uji reliabilitas dalam penelitian ini dilakukan dengan menghitung koefisien Cronbach's Alpha dari tiap-tiap instrumen suatu variabel. Skala dapat dinyatakan andal apabila dalam pengujian reliabilitas diperoleh nilai Cronbach's alphadi mendekati 1,00 (Azwar, 2010). Perhitungan uji validitas dan reliabilitas 
skala dihitung dengan menggunakan bantuan program computer SPSS for windows 7 versi 22.0.

Berdasarkan hasil perhitungan pengujian reliabilitas dari jumlah 45 aitem pernyataan $(\mathrm{N})$ skala kecerdasan emosi yang valid, maka dapat dilihat bahwa nilai koefisien alpha cronbach $(\alpha)$ menunjukkan angka 0,915 kecerdasan emosi. Angka 0,915 tersebut yaitu hampir mendekati angka 1 (satu), sehingga dapat dinyatakan bahwa skala kecerdasan emosi adalah reliabel.

\section{HASIL DAN PEMBAHASAN}

Berdasarkan hasil penelitian yang telah dilakukan pada 35 perawat lakilaki, menunjukan bahwa terdapat $(1,16 \%)$ atau 1 perawat laki-laki memiliki kecerdasan emosi yang sangat tinggi,(13.95\%) atau 12 perawat laki-laki memiliki kecerdasan emosi yang tinggi, (12,79\%)atau 11 perawat laki-laki memiliki kecerdasan emosi yang sedang, $(12,79 \%)$ atau 11 perawat laki-laki memiliki kecerdasan emosi yang rendah.

Kemudian berdasarkan hasil penelitian yang telah dilakukan pada 59 perawat perempuan, menunjukan bahwa terdapat $(6,78 \%)$ atau 4 perawat perempuan memiliki kecerdaan emosi yang sangat tinggi, (18,64\%) atau 11 perawat perempuan memiliki kecerdaan emosi yang tinggi, (44,07\%) atau 26 perawat perempuan memiliki kecerdaan emosi yang sedang, (28,81\%) atau 17 perawat perempuan memiliki kecerdaan emosi yang rendah, (1,69\%) atau 1 perawat perempuan memiliki kecerdaan emosi yang sangat rendah

Berdasarkan hasil dari pengujian hipotesis dengan menggunakan teknik "uji-t", diperoleh $t_{\text {hitung }}$ sebesar 4.879 dengan nilai probabilitas 0,000 , oleh karena itu $\mathrm{t}_{\text {tabel }}$ dengan df ( $\left.\mathrm{n}-2\right)$ sebesar 92 dan menggunakan taraf signifikansi 1\% $(0,01)$ yaitu sebesar 2,630, maka $\mathrm{t}_{\text {hitung }}>\mathrm{t}$ tabel yaitu $(4,879>2,630)$ dan nilai probabilitas lebih kecil dari $1 \%(0,01)$ yaitu $(0,000<0,01)$ sehingga dapat dinyatakan bahwa hipotesis pada penelitian ini adalah diterima. Dengan demikian, maka dapat diambil sebuah kesimpulan bahwa ada perbedaan yang signifikan kecerdasan emosi antara perawat laki-laki dengan perawat perempuan di Rumah Sakit Wijaya Kusuma Purwokerto. Hasil pengujian hipotesis yang telah dilakukan dengan menggunakan teknik uji-t,

Berdasarkan deskripsi data melalui hasil uji mean, maka diketahui bahwa mean untuk kecerdasan emosi perawat laki-laki yaitu 149.06 lebih besar dari mean kecerdasan emosi perempuan yaitu 135.63. Dengan standar deviasi (SD) kecerdasan emosi perawat laki-laki yaitu 14.138 dan standar deviasi (SD) kecerdasan emosi perempuan yaitu 12.117. Berdasarkan hasil diatas, maka dapat dinyatakan bahwa tingkat kecerdasan emosi perawat laki-laki lebih tinggi dibandingkan kecerdasan emosi perawat perempuan (149.06>135.63).

Beberapa penelitian menemukan bahwa wanita lebih menyadari emosi mereka, menunjukkan empati dan lebihbaik dalam hubungan interpersonaldibandingkan dengan pria. Goleman juga (1997) mengatakan wanita 
lebih beruntung pada lingkungan sosial yang lebih menekankan kepada emosi daripada pria.

Golamen (1997 menjelaskan tentang kecerdasan emosional pada kaum pria dan wanita, dimana kaum pria yang tinggi kecerdasan emosionalnya secara sosial mantap, mudah bergaul dan jenaka serta tidak mudah takut atau gelisah.Berkemampuan besar untuk melibatkan diri dengan orang-orang atau permasalahan, untuk memikul tanggungjawab, dan mempunyai pandangan moral.Simpatik dan hangat dalam hubungan-hubungan mereka.Kehidupan emosional mereka kaya tetapi wajar, mereka merasa nyaman dengan dirinya sendiri, dengan orang lain, dan dunia pergaulan lingkungannya.Sedangkan kaum wanita yang cerdas secara emosional cenderung bersikap tegas dan mengungkapkan perasaan mereka secara langsung, dan memandang dirinya secara positif serta memberi makna kehidupan bagi mereka.Sebagaimana kaum pria, mereka mudah bergaul dan ramah serta mengungkapakan perasaan mereka dengan takaran yang wajar.Mampu menyesuaikan diri dengan beban stress.Kemantapan pergaulan mereka membuat mereka mudah menerima orang baru, mereka cukup nyaman dengan dirinya sendiri sehingga selalu ceria, spontan, dan terbuka terhadap pengalaman-pengalaman kaum pria.

\section{KESIMPULAN}

Ada perbedaan yang signigfikan kecerdasan emosi perawat laki-laki dengan perawat perempuan di Rumah Sakit Wijayakusuma Purwokerto. Tingkat kecerdasan emosi yang dimiliki oleh perawat laki-laki lebih tinggi dibandingkan dengan kecerdasan emosi yang dimiliki oleh perawat perempuan.

\section{DAFTAR PUSTAKA}

Arikunto, S. (2010). Prosedur Penelitian : Suatu Pendekatan Praktik. Jakarta : PT. Rineka Cipta.

Azwar, S., (2010). Metode Penelitian., Yogyakarta: Pustaka Belajar.

Goleman, D. (1997). EQ, Kecerdasan Emosional (Mengapa EQ Lebih Penting Daripada IQ ). Jakarta: PT. Gramedia Pustaka Utama.

Goleman, D., (2000), Working With Emotional Inteligences "Kecerdasan Emosioanal Untuk Mencapai Puncak Prestasi". Jakarta : Gramedia Pustaka Utama.

Saryono. (2011). Metodologi penelitian kesehatan: penuntun praktis bagi pemula. Yogyakarta: Mitra Cendikia Press.

Suryabrata, S. (2005). Pengembangan Alat Ukur Psikologis. Yogyakarta: Andi. 
SATRIO NUGROHO \& RETNO DWIYANTI, Perbedaan Kecerdasan Emosi Antara Perawat Laki-Laki Dan Perawat Perempuan...

Sugiyono. (2007). Metode Penelitian Kuantitatif dan Kualitatif, R\&D. Bandung: CV. Alfabeta. 